\title{
Livelihood implications of artisanal gold mining in farming communities: insight from the Wa East District, Ghana
}

\author{
Issah Baddianaah ${ }^{\mathrm{a}}$ \\ Gordon N-yelkabo Tuu ${ }^{\mathrm{b}}$ \\ Bernard Nuoleyeng Baatuuwie ${ }^{\mathrm{b}}$
}

\begin{abstract}
The impact of artisanal mining on livelihoods in developing countries is a contentious issue. As a contribution to this subject, the study assessed the implications of artisanal gold mining activities on smallholder agriculture in the Wa East District of Ghana. A descriptive survey design with a mixed methods research approach was used. Primary data were sourced from respondents through interviews, questionnaire administration, and field observation. Five artisanal mining communities were selected based on the intensity of mining activities in them. The study respondents consisted of 290 household heads drawn randomly from 1,050 households. Also, key informants consisting of 5 assembly members and 15 lead artisanal miners were interviewed. The study found artisanal mining to be a dominant livelihood strategy in the district, employing about $76.2 \%$ of respondents at various levels. Artisanal mining contribution to household income was higher than food crop farming. Proceeds from mining are used to finance smallholder agriculture. However, the activities of the miners have resulted in the degradation of farmlands. We argued that artisanal mining activities should be aligned with other livelihood options such as agriculture in local communities. The study called for the engagement of local miners and traditional rulers in mineral resource decision-making.
\end{abstract}

Keywords: Smallholder agriculture; artisanal mining; diversification; environmental effects; rural areas; sustainability

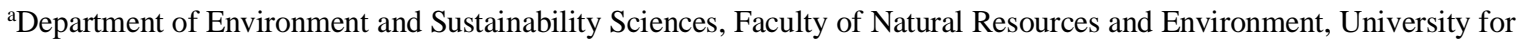
Development Studies_ ${ }^{b}$ Department of Geo-Information Sciences, Faculty of Natural Resources and Environment, University for Development Studies

${ }^{a}$ Corresponding Author: Email: yakubuissah1983@gmail.com
}

Received on March 5 ${ }^{\text {th }}$,2021/ Accepted on November 27 ${ }^{\text {th }}$, 2021/ Published online on December 19, 2021

Ghana Journal of Geography Vol. 13 (3), 2021 pages 85-120

Doi: https://dx.doi.org/10.4314/gjg.v13i3.5 


\section{Introduction}

Ghana's economy has been dominated by the agriculture sector for the past decades (Ayee et al., 2011; Boateng et al., 2014). Conversely, in recent years, the output from the agriculture sector continues to decline because of climate variability (high daily temperatures, erratic rainfall patterns), and the outbreak of pests and diseases. The communities mostly affected by the climatic change are rural communities in the northwestern part of Ghana whose dwellers are traditional food crop farmers (Mumin, 2017; Apuri et al., 2018; Baddianaah et al., 2020). It, therefore, stands to reason that local communities in this part of the country cannot solely rely on the agriculture sector for livelihood sustenance. These agriculture-dependent communities are compelled to explore alternative livelihood strategies to complement food crop farming. Consequently, the search for new sources of livelihood has compelled some of these rural folks into artisanal mining operations (Agyemang \& Okoto, 2014; Bagah et al., 2016; Osumanu, 2020). Artisanal mining operations in some communities are rated as being more lucrative than food crop farming (Funoh, 2014). While the question on the lucrative nature of ASM remains a debate amongs academics, the environmental tragedies of artisanal mining operations on rural agriculture dominates the literature (Hilson, 2016).

Artisanal mining has been practiced in Ghana as far back as the 4th century (Ofosu-Mensah, 2011). The Small-Scale Mining Law (Provisional National Defence Council Law [PNDCL 218]), 1989, and the Minerals and Mining Act, 2006 (Act 703) limit small-scale mining to Ghanaians (Crawford \& Botchwey, 2016). The aim of this limitation is to provide Ghanaian citizens with a source of livelihood. However, most artisanal and small-scale miners find it difficult to register and obtain licenses before operating. The lack of licence by most nationals in 
Livelihood implications of artisanal gold mining in farming communities: insight from the Wa East District, Ghana

the small-scale mining sector is blamed on the difficulty, bureaucracy, cost, and time involved in obtaining the license in Ghana (Hilson et al., 2014). Thus, most artisanal and small-scale miners continue to operate without the necessary documents (McQuilken \& Hilson, 2016). This has made the artisanal mining sector to be viewed as illegal (Crawford \& Botchwey, 2016).

Artisanal mining is fundamentally conceived as mining by individuals or groups that use simple tools and methods in extracting minerals such as gold, diamond manganese, and bauxite. It takes place in the informal sector where these miners have no formal or legal documents to operate (McQuilken \& Hilson, 2016). Artisanal mining is popularly called galamsey in Ghana, which means gather and sell (Akabzaa \& Darimani, 2001; Awumbila \& Tsikata, 2004; Ofosu-Mensah, 2011). However, mining operations that use similar technology as in the case of artisanal mining but are duly registered are termed as small-scale mining. Artisanal and small-scale mining (ASM) operations have become a daily livelihood activities to dwellers of mineral-rich communities across Ghana, as everyone's interest is now focused on the sector (Hilson \& Garforth, 2012). Approximately, one million Ghanaians are directly involved in artisanal and small-scale mining operations whilst closed to 1.5 million Ghanaians are indirect beneficiaries of the sector (McQuilken \& Hilson, 2016). In addition, the ASM sector accounted for about 1.4 million ounces (34\%) of the total quantity of gold produced in Ghana, $6 \%$ of GDP, and $28.3 \%$ of government revenue between 2010 and 2012 (Ministry of Lands and Natural Resources [MLNR], 2012).

The aforementioned successes of the artisanal and small-scale mining sector have been attributed to the cogent role played by the British-Ghana's colonial masters. Though artisanal and smallscale mining is an indigenous and informal way of extracting minerals, the advent of colonial 
rule brought a paradigm shift into the artisanal and small-scale mining sector of Ghana (OfosuMensah, 2011). The unregulated nature of the operations of artisanal and small-scale miners was viewed as not profitable to Ghana's economy but only improved the economic status of individuals; some of whom were foreigners (Awumbila \& Tsikata, 2004). This culminated in the promulgation of the Small-Scale Mining Law in 1989, PNDCL 218 to regulate the economic, social, and environmental impacts of artisanal and small-scale mining activities in the country (Akabzaa \& Darimani, 2001).

Besides, other enactments recognized along the chain of mining and its related activities as noted by Akabzaa \& Darimani (2001) include the Minerals and Mining Law of 1986 (PNDCL 153), as amended by the Minerals and Mining (Amendment) Act of 1994 (Act 475); the Investment Promotion Act of 1994 (Act 478); the Additional Profits Tax Law of 1985 (PNDCL 122); the Minerals Commission Law of 1986 (PNDCL 154); the Minerals (Royalties) Regulations of 1987 (LI 1349); the Environmental Protection Agency (EPA) Act of 1994 (Act 490), and the Environmental Assessment Regulations, LI 1652 of 1999. Notwithstanding the enactment of these laws to govern and sanitize the ASM sector of Ghana, much has not been achieved in the sector in terms of social, economic, and environmental sustainability (Redehey, 2017; AdontengKissi \& Adonteng-Kissi, 2018).

Successive governments in Ghana continue to battle with the adverse effects associated with artisanal and small-scale mining activities. For instance, as of 2016, the Ghana government allocated US\$6,424.1 to flush out illegal miners (Boadi et al., 2016). This was because the participation of other nationals in the artisanal and small-scale mining sector of Ghana aggravated its negative effects (Crawford \& Botchwey, 2016). This resulted in many scholars 
Livelihood implications of artisanal gold mining in farming communities: insight from the Wa East District, Ghana

focusing on the negative environmental and social ramifications to the neglect of its economic prospects (Hilson et al., 2014). The negative environmental consequences of artisanal and smallscale mining operations, particularly on water resources became so pronounced in Ghana, prompting the president of Ghana to constitute a combined police and military task force known as "Operation Vanguard" to enforce the small-scale mining law (Adonteng-Kissi \& AdontengKissi, 2018; Owusu et al., 2019). Subsequently, all forms of artisanal and small-scale mining activities (registered and unregistered) were banned in March 2017. Upon successfully developing a comprehensive policy framework to regularize small-scale mining by the InterMinisterial Committee on Illegal Mining (IMCIM), the small-scale mining ban was lifted on December 17, 2018, for only registered and vetted miners to mine (Owusu et al., 2019). The new mining policy framework now mandates about $70 \%$ of the hitherto small-scale miners to reapply for new licenses. As this has demonstrated to be an effective way of limiting the adverse effects of artisanal mining in Ghana, we are uncertain about the capacity of local miners to meeting the legal requirements of mining. This could lead to the alienation of these local miners from engaging in artisanal mining operations unless the government proposed Community Mining Cooperative (CMC) concept is fully implemented. However, one surest way to understand the effects of artisanal mining across rural communities is to appreciate its relationship with other prevailing livelihood strategies, particularly smallholder farming (Hilson, 2016; Osumanu, 2020).

The Wa East District is of particular interest to this study owing to the large population of its youth that engaged in artisanal mining operations. While the number of artisanal miners continues to increase in the district, a study conducted by Agyemang \& Okoto (2014) showed 
that these activities come with some negative environmental effects. Prominent among these negative effects include the degradation of farmlands and water pollution. In another related study, Bagah et al. (2016) reported a scuffle that ensued between smallholder farmers and artisanal miners in the district. Farmlands in the district are subjected to mining activities with a substantial majority of the youth showing greater interest in mining compared to farming (Agyemang \& Okoto, 2014; Baddianaah et al., 2021). Moreover, the relationship between ASM and agriculture remains unsettled in the extant literature. It is against this background that, this study seeks to assess the contribution of artisanal mining operations to the livelihoods of smallholder households in the Wa East District. The overarching research question guiding the study was: how do artisanal mining activities affect livelihoods in the Wa East District? Specifically, the following research questions were raised:

(1) What is the contribution of artisanal mining to smallholder agriculture in the Wa East District?

(2) What is the contribution of artisanal mining to local community development in Wa East District?

(3) How do local communities perceive the adverse environmental and social effects of artisanal mining activities in the Wa East District?

The study will contribute to knowledge on the linkages between artisanal mining operations and smallholder agriculture. This would provide insight into advancing sustainable artisanal mining strategies across farming communities.

\section{Theoretical underpinning}

We analysed the data in this work by employing the theoretical tenets of accumulation by dispossession (Harvey, 2003). From Harvey's conceptualization of the neoliberal capitalist 
policies in the developed world, from the 1970s till date, and building upon Marxist (1976) primitive accumulation, he lamented the centralization of wealth and power in the hands of few wealthy individuals by dispossessing the masses, mostly poverty-stricken and vulnerable groups in society. He defined this as accumulation by dispossession (Caceres, 2015). We view the happenings in Ghana's mining sector particularly, the alienation of the locals from mining (Kidido et al., 2015) as indistinguishable from accumulation by dispossession. The Small-scale Mining Law (PNDCL, 218) as amended by the Minerals and Mining Act, 2006 (Act 703) though of great significance in redefining artisanal mining in Ghana, has failed to secure a defined position for local miners. The formalization and commercialization of the small-scale mining sector rather benefit a few wealthy individuals who have the financial backing to operate. Besides, it promotes what could best be described as clientelism in the mining sector of Ghana with its accompanying socio-economic implications on livelihoods of local communities (Crawford \& Botchwey, 2016; Abdulai, 2017).

In this study, we do not explore all primitive accumulation by dispossessing arguments like wage labour dispossession. Also, we focuse on the not general form of land privatization but lands that are still owned by locals as being practiced in the Wa East District. Ghana land tenure regimes are dominated by customary ownership ( 80 percent) best described as chiefs and stool lands (Kidido et al., 2015). However, despite the right to land by an individual, group, family, or community, ownership of mineral resources is the exclusive right of the state. The Constitution of Ghana states that: 'every mineral in its natural state in, under or upon the land in Ghana, is the property of the republic and is vested in the President in trust for the people of Ghana' (Republic of Ghana, 2006). The constitution further states categorically that: "despite a right or title which 
a person may have to land in, upon or under which minerals are situated, a person shall not conduct activities on or over land in Ghana for the search, reconnaissance, prospecting, exploration or mining for a mineral unless the person has been granted a mineral right under Act 703." (Republic of Ghana, 2006).

This constitutional provision has empowered state institutions at the expense of traditional rulers and local miners (Osei-Kojo \& Andrews, 2016). Attempts to justify the rationale for limiting resource exploitation to the state are often tailored to conservationists' viewpoints such as preventing land degradation, and ecological resource depletion (Crawford \& Botchwey, 2016). As these principles are upheld, the gains from perceived miners that meet environmental clearance are being accumulated and shared by minority wealthy groups, mostly government functionaries and politicians at the expense of the vulnerable local dwellers (Crawford \& Botchwey, 2016; Abdulai, 2017; Adonteng-Kissi, 2017). Scholars share the notion that the small-scale mining law in Ghana has not been enforced (Crawford \& Botchwey, 2016; United Nations Development Programme [UNDP] Ghana, 2016; Owusu et al., 2019). This has led to a high level of collusion and collaboration between state agencies, chiefs, and wealthy illegal miners who are permitted to mine on illegal grounds (Crawford \& Botchwey, 2016). Additionally, most communities endowed with mineral resources are often deprived of the benefits of mining by large-scale mining companies (Adonteng-Kissi, 2017). Mineral royalties are paid to the government for redistribution to all the parties concern, in which case mining communities receive little or not all in some instances (Kidido et al., 2015). The system of benefits sharing in the mining sector in Ghana is built on the clientelist approach (Abdulai, 2017). A local miner's chance of mining is being explained by his or her ability to establish 
strong ties with the political party in power (Crawford \& Botchwey, 2017). This does not allow for a holistic evaluation and reflection of the true contribution of artisanal mining operations across local communities.

\section{The sustainable livelihood approach}

The Sustainable Livelihood Approach discusses the relevance of sustainable livelihood in poverty reduction (DFID, 2000). It points out how poverty affects the livelihoods of people living in rural communities and the contribution of their assets to their livelihood (Osumanu, 2020). According to Krantz (2001), the sustainable livelihood approach takes its roots from the Brundtland Commission report on Environment and Development in 1989. It was further developed by the 1992 United Nations Conference on Environment and Development, stressing on the achievement of sustainable livelihood as a broad goal for poverty eradication. Following this, several academics (e.g. Chambers \& Conway, 1992; Scoones, 1998; Krantz, 2001) have made concerted efforts to come out with a concise definition of the concept of sustainable livelihood. Chambers \& Conway (1992:6) defined sustainable livelihood as follows: “...a livelihood comprises the capabilities, assets (stores, resources, claims, and access) and activities required for a means of living; a livelihood is sustainable when it can cope with and recover from stress and shocks, maintain or enhance its capabilities and assets, and provide sustainable livelihood opportunities for the next generation; and which contributes net benefits to other livelihoods at the local and global levels and in the short and long-term". Krantz (2001) argued that any definition of livelihoods sustainability must contain the ability to avoid or withstand and recover from stresses and shocks. Artisanal mining is a livelihood activity that has both positive and negative outcomes including stresses and shocks. Artisanal mining is driven by poverty with 
rural people depending on their natural resources to sustain their livelihoods (Andrew, 2015; Hilson, 2016; Mapuva \& Dube, 2016; Osumanu, 2020). The sustainable livelihood framework focuses on the livelihood of the poor, with poverty reduction as its main objective. Development work has to focus on lessening or reducing the burden of the poor. Sustainable resource extraction does not mean preventing minority groups from benefiting from the resources. It has to do with environmentally friendly means of resource extraction. According to Krantz (2001), the portfolio of livelihood assets is the most significant aspect of the sustainable livelihood framework with complexities. It is the component of the framework that accommodates both the tangible and intangible assets such as claims and access as means through which people create a living.

Streamlining Ghana's artisanal mining sector requires upholding the livelihood trajectory of the operations (Owusu et al., 2019). Thus, policymakers must recognize the position of local miners and the forces behind their operations (Osei-Kojo \& Andrews, 2016). In addition, the people themselves must be involved in identifying their priority aspects of livelihood that need intervention (Morse \& McNamara, 2013). This promotes the participation of local people in the design of policies and projects that are intended to better their lives. Thus, it increases motivation, commitment, and empowerment of the local people. Again, the role of donors and other agencies including academics should target facilitating processes that will help the poor unearth their priorities and analyse them around their available resources. Finally, development should have a long term focus. Poverty reduction demands more than economic growth. Poverty does not imply only monetary income; it has a significant relationship with health and education, and less tangible entities such as a sense of "powerlessness" (Krantz, 2001). 
In this study, we argue that the government's attempt to redefine small-scale mining in Ghana is likely to take a political posture. The government promised to put local miners into community mining cooperatives and thus, allocate them concessions to mine. However, upon lifting the small-scale mining ban in December 2018, only registered small-scale miners have been certified to mine whilst local miners continue to wait in vain. Thus, their livelihood in mining has been truncated. It has been argued that the approach taken by the government has little if any, to address the fundamental challenges facing artisanal and small-scale mining operations in Ghana (Owusu et al., 2019). We posit that local miners should have been involved in planning, development, and implementation of the new small-scale mining policy framework. Hence, we share the view that any attempt to make artisanal mining a sustainable livelihood strategy must incorporate local miners into the design and implementation process. Failure to do so will degenerate into accumulation by dispossession tendency. To fully address the ramifications of artisanal and small-scale mining activities across local communities, there is need for a an understanding of the livelihoods trajectory of artisanal mining across local communities.

\section{Materials and Methods}

\section{Study area}

The study was undertaken in the Wa East District of the Upper West Region of Ghana. The Wa East District has an area of about $1,078 \mathrm{~km}^{2}$. It lies between latitudes $9^{\circ} 55^{\prime} \mathrm{N}$ and $10^{\circ} 25^{\prime} \mathrm{N}$ and longitude $1^{\circ} 10^{\prime} \mathrm{W}$ and $2^{\circ} 5^{\prime} \mathrm{W}$ (Figure 1). The vegetation of the Wa East District is guinea savannah woodland. More than $30 \%$ of the natural vegetation has been destroyed by annual bush fires, indiscriminate cutting of trees for fuelwood, and artisanal gold mining. The District 
consists mainly of pre-Cambrian base rock, granite, and metamorphic rock types. These rocks offer mining opportunities. The soils are mainly sandy and loamy. They are very fertile soils and are suitable for the cultivation of tubers, cereals, and legumes. Livestock are also reared on a large and small-scale basis in the district (Ghana Statistical Service, 2014).

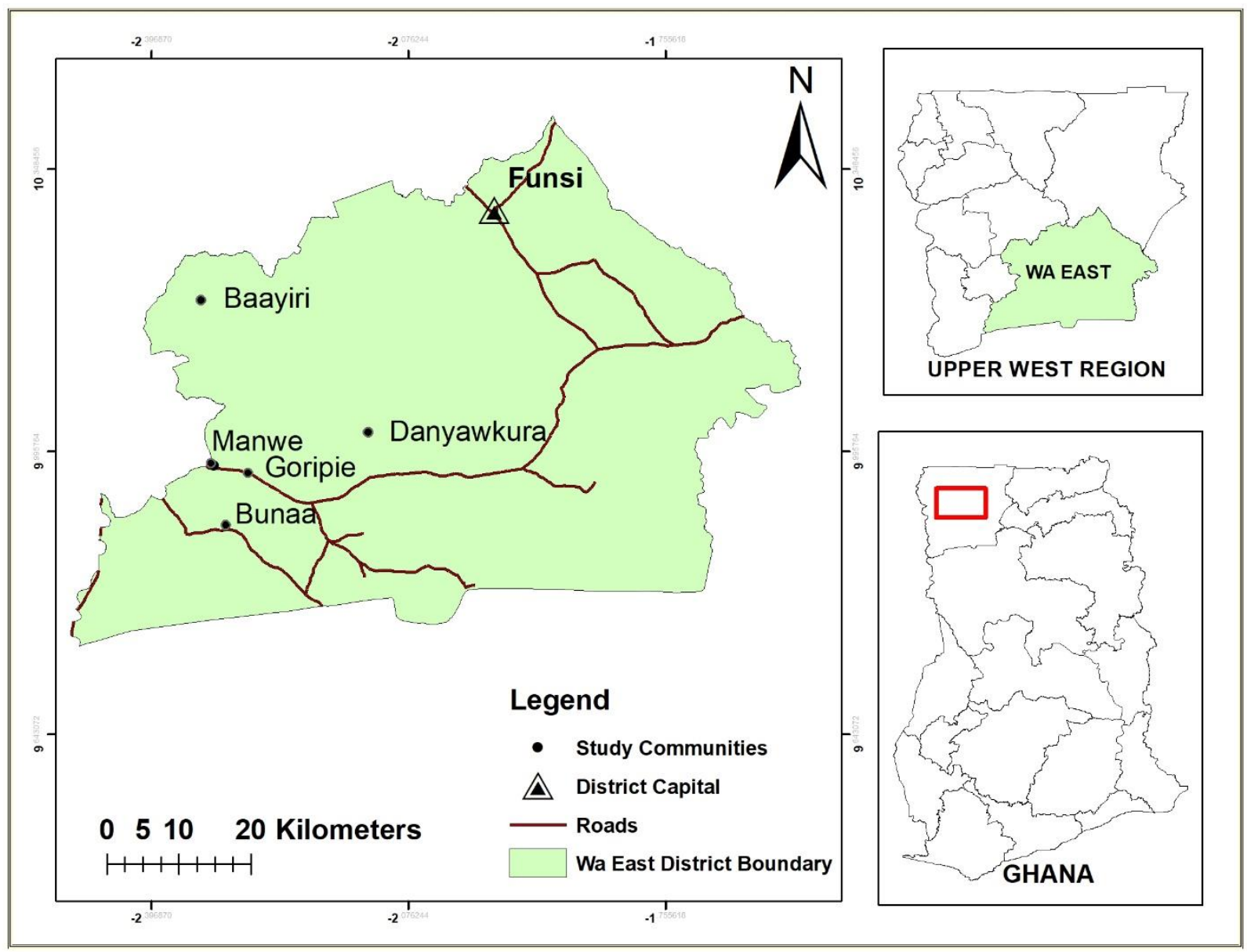

Figure 1: Map of Wa East District

Source: Ghana statistical Service (2014)

\section{Methods of the Study}

A descriptive survey research design embodying qualitative and quantitative approaches was used to gather relevant data for the study. The descriptive survey design enables the researcher to 
Livelihood implications of artisanal gold mining in farming communities: insight from the Wa East District, Ghana

deal with issues relating to the prevailing environmental phenomena, practices, beliefs, processes, relationships, or trends of the respondents (Aggarwal, 2008; Panneerselvam, 2011). The mixed methods research approach was adopted taken into consideration the need to combine both qualitative and quantitative variables of the study participants (Creswell, 2014). The mixed methods research approach allows for methodological complementarity, thereby, ensuring a formidable research design and strengthen the validity and reliability of the findings (Neuman, 2014). This approach is unbiased and neutralizes the weaknesses associated with single use of the qualitative and quantitative methods (Creswell, 2014).

Multiple sampling strategies involving purposive sampling, simple random sampling, and snowball sampling techniques were employed in selecting the study respondents. The first sampling step taken involved the selection of the local artisanal mining communities. Fifteen (15) artisanal mining communities were identified in the Wa East District. However, recent intensity and dominance of the operations of artisanal miners across the communities were taken into account in selecting the study communities. Thus, five (5) mining communities, namely, Baayiri, Goripie, Manwe, Buna, and Danyawkuraa were purposively selected for the study. The purposive sampling of mining communities was considered relevant because the researcher was curious about establishing the prevailing relationship that existed between artisanal mining operations and smallholder agriculture. Therefore, the livelihood implications of artisanal mining would be best appraised in areas where the activity is actively ongoing. In this case, a random sample may not be appropriate since dormant artisanal mining communities were likely to be included in the study, depriving the study of the current status and reflection of artisanal and small-scale mining operations in local communities. Additionally, households were selected by 
employing a simple random sampling technique within the selected mining communities where each household head was selected to complete a questionnaire. In the event of multiple households within a housing unit, especially in a compound house, the simple random sampling technique was again applied in the selection of household head to complete the survey questionnaire. The sampling frame for the study was obtained by adding all households in the selected communities as presented by the Ghana Statistical Service (2014), where a sample size determination formula by Yamane (1967) was used to calculate the sample size. Table 1 shows the number of households by communities and the proportion of sample distribution. Therefore, using the sample frame of 1,050 households in the study area, the sample size was calculated using the formula outlined by Yamane (1967) as follows:

$\mathrm{n}=\frac{N}{1+N(e)^{2}}$ equ.[1].

Where the study sampling frame, $\mathrm{N}=(1050)$; error or significance level, $\mathrm{e}=(0.05)$. The desired sample size was estimated as:

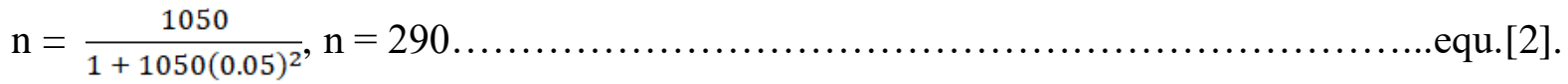

Table 1: Number of Households and Sample Distribution

\begin{tabular}{lll}
\hline Name of Community & Number of Households & Sample Proportion \\
\hline Baayiri & 248 & 68 \\
Goripie & 325 & 90 \\
Manwe & 254 & 70 \\
Buna & 162 & 45 \\
Danyawkura & 61 & 17 \\
\hline Total (Sample Frame) & 1050 & 290 \\
\hline
\end{tabular}

Source: Field Survey (2017) 
The simple random sampling technique gives each respondent an equal chance of being selected for the study (Bhattacherjee, 2012; Neuman, 2014). It is simple, unbiased and inferences can be generalized (Creswell, 2014). Random numbers were generated using excel and used in the selection of households. Household heads were chosen because they are the main decisionmakers within the household level. They stand the chance of influencing or determining the choice of livelihood strategy including financial decisions of the household (Osumanu, 2020; Baddianaah et al., 2020). Also, the snowball sampling technique was used in reaching out to three (3) leaders (bosses) of artisanal miners in each community (i.e. a total of fifteen bosses). The snowball sampling technique was adopted because, at the time of the survey, there was a government ban on artisanal and small-scale mining. However, these miners were defying government orders and were mining illegally. This, therefore, made it very difficult for the researcher to easily identify them, if not through snowballing. The last set of participants of the study were the Assembly Members who were purposively sampled and included in the survey because they are major stakeholders of their communities. These groups of participants (artisanal miners' leaders and assembly members) were treated as key informants and interviewed.

The study used primary data gathered through key informant interviews, questionnaires, and field observation. Semi-structured questionnaires (involving both closed and open-ended questions) were designed and administered to 290 respondents (household heads) in the five (5) sampled study communities. The household questionnaire was deployed towards elucidating the contributions of ASM with focus on the respondents' level of participation in artisanal mining operations including the timeframe, economic benefits of ASM, linkages between ASM and agriculture, prospects, and challenges, and the adverse effects of ASM in the study communities. 
However, the first section of the questionnaire captures the socio-demographic variables of the respondents. Key informant interviews were conducted for lead miners, soliciting their views on the prospects and challenges of ASM, artisanal miners' relationship with ASM regulatory institutions, and the effects of ASM on agriculture in their communities. Finally, Assembly

members within the study communities were interviewed on the prospects and challenges of ASM operations within their jurisdiction and their position about the future of ASM. Each interview session lasted between 30 to 60 minutes. Finally, through field visits and transect walks, the mining environment was observed by the researchers with the aid of an observation guide. The entire data collection process lasted for about 4 months-from September to December 2017.

The methods of data analysis include coding and entering the data into the Statistical Package for Social Sciences (SPSS) version 20 spreadsheet where appropriate transformations were done. Descriptive statistics (central tendency), frequency counts and percentages, crosstabulation, and correlation were used in analysing the quantitative data and presented using tables and figures. Qualitative data (voices) of lead miners (bosses) and Assembly members were recorded, transcribed, and presented in direct and indirect quotations. This was analysed based on content and thematic judgment.

\section{Results and Discussion}

\section{Socio-demographic characteristics of respondents}

The majority (89.7\%) of the respondents (household heads) were males (Table 2). Gender played a significant role in household headship in most African societies. The wife assumes leadership 
Livelihood implications of artisanal gold mining in farming communities: insight from the Wa East District, Ghana

roles within the household in the absence of the husband. Mihaye (2013) found that male household heads dominate (80\%) in southern Ghana in a study involving households of ASM communities in the East Akim Municipality. This finding suggests a gender gap in household leadership in Ghana.

The mean age of the respondents was 40.5 and the mean household size was 8 with a maximum of 30 people in a household. The maximum number of people a respondent fed was 30 while the average number of children per household head was 4 (Table 2). The age distribution of the population suggests that the population is economically active and if effectively used would result in improved socio-economic development. However, this economically active population coupled with an increase in childbirth (an average of 4 biological children per household head) will have concomitant effects on dependency. Thus, it would be reasonable to argue that most household heads in the Wa East District are attracted to artisanal gold mining as a supplementary income source to provide for the needs of the growing household population. This corroborates the findings of related scholars pointing to large household sizes and associated basic needs of the household as push factors for the proliferation of ASM activities in local communities (McQuilken, \& Hilson, 2016; Mapuva \& Dube, 2016; Owusu et al., 2019; Osumanu, 2020).

Table 2: Socio-demographic variables

\begin{tabular}{|c|c|c|c|c|c|}
\hline \multicolumn{2}{|l|}{ Sex of Respondent } & \multicolumn{2}{|l|}{ Frequency } & \multicolumn{2}{|l|}{ Percent } \\
\hline Male & & 260 & & 89.7 & \\
\hline Female & & 30 & & 10.3 & \\
\hline Variable & $\mathrm{N}$ & Minimum & Maximum & Mean & Std. Deviation \\
\hline Age of respondent & 290 & 23 & 71 & 41 & 9.41 \\
\hline Household size & 290 & 1 & 30 & 7 & 4.15 \\
\hline Biological children & 254 & 1 & 20 & 4 & 3.05 \\
\hline People fed & 276 & 1 & 30 & 8 & 4.87 \\
\hline Number of students & 259 & 1 & 15 & 4 & 2.46 \\
\hline
\end{tabular}

Source: Field Survey, 2017 
Figure 2 shows $44.8 \%$ of the respondents had no formal education, $6.6 \%$ had a first degree while $0.7 \%$ obtained postgraduate education. The low level of formal educational attainment implies that the majority of the people in the Wa East District may not have the skills and training needed to work in the formal sector. Thus, informal jobs particularly in the primary sector such as farming and artisanal mining remain their major sources of employment.

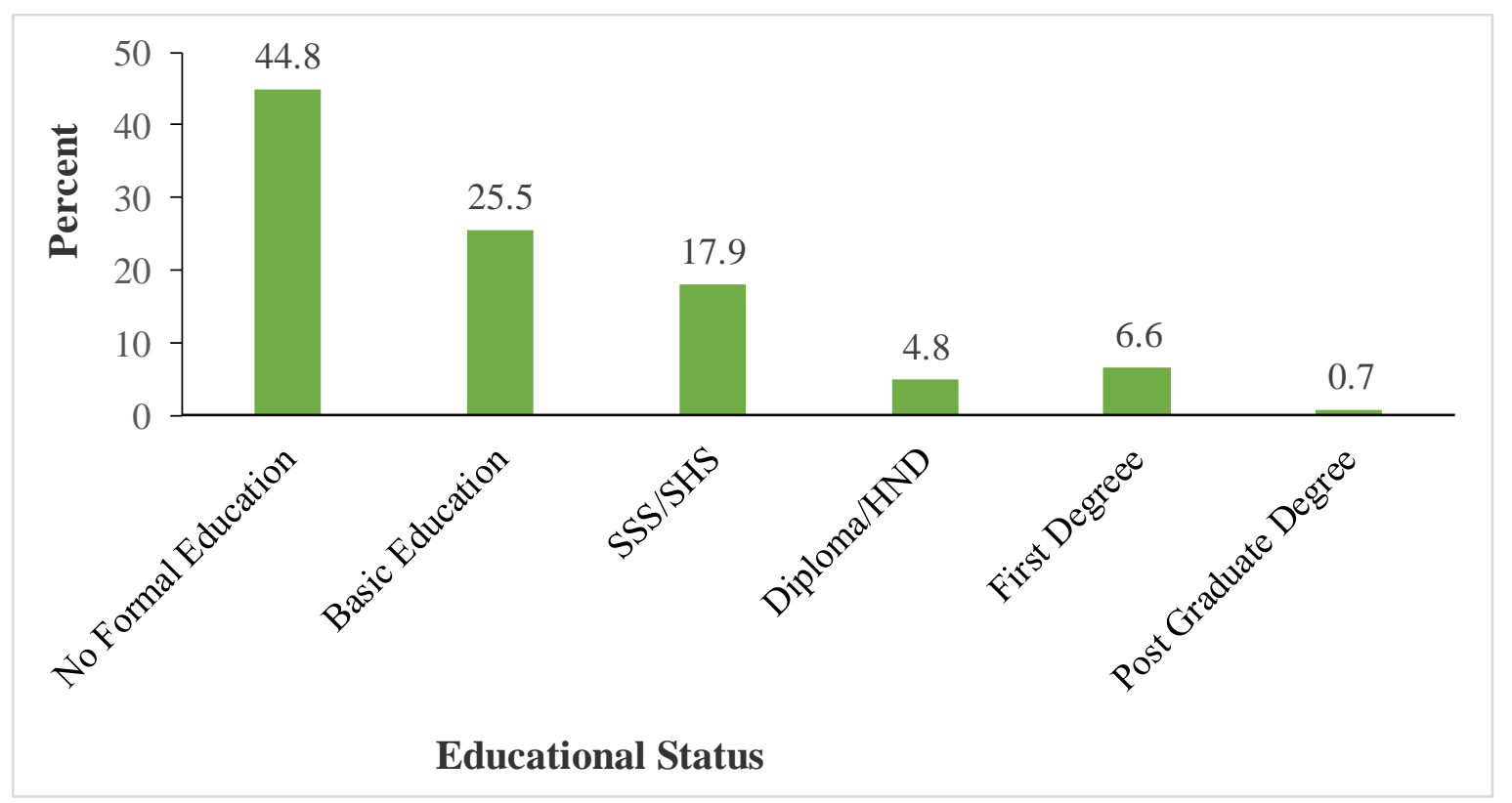

Figure 2: Educational status of respondents Source: Field Survey (2017)

Furthermore, about $44.8 \%$ of the respondents engaged in farming as their main occupation while ASM employed $32.1 \%$ of the study population. Other sectors that employed the study respondents include trading and related artisan works. However, about $9.7 \%$ of the respondents were found to be employed in the formal sector-the public and civil services. The results show that a majority of the respondents engaged in the informal sectors and may be attracted to ASM 
Livelihood implications of artisanal gold mining in farming communities: insight from the Wa East District, Ghana

activities since ASM is one of the lucrative jobs for rural dwellers in Ghana (Fearon et al., 2015; Owusu et al., 2019).

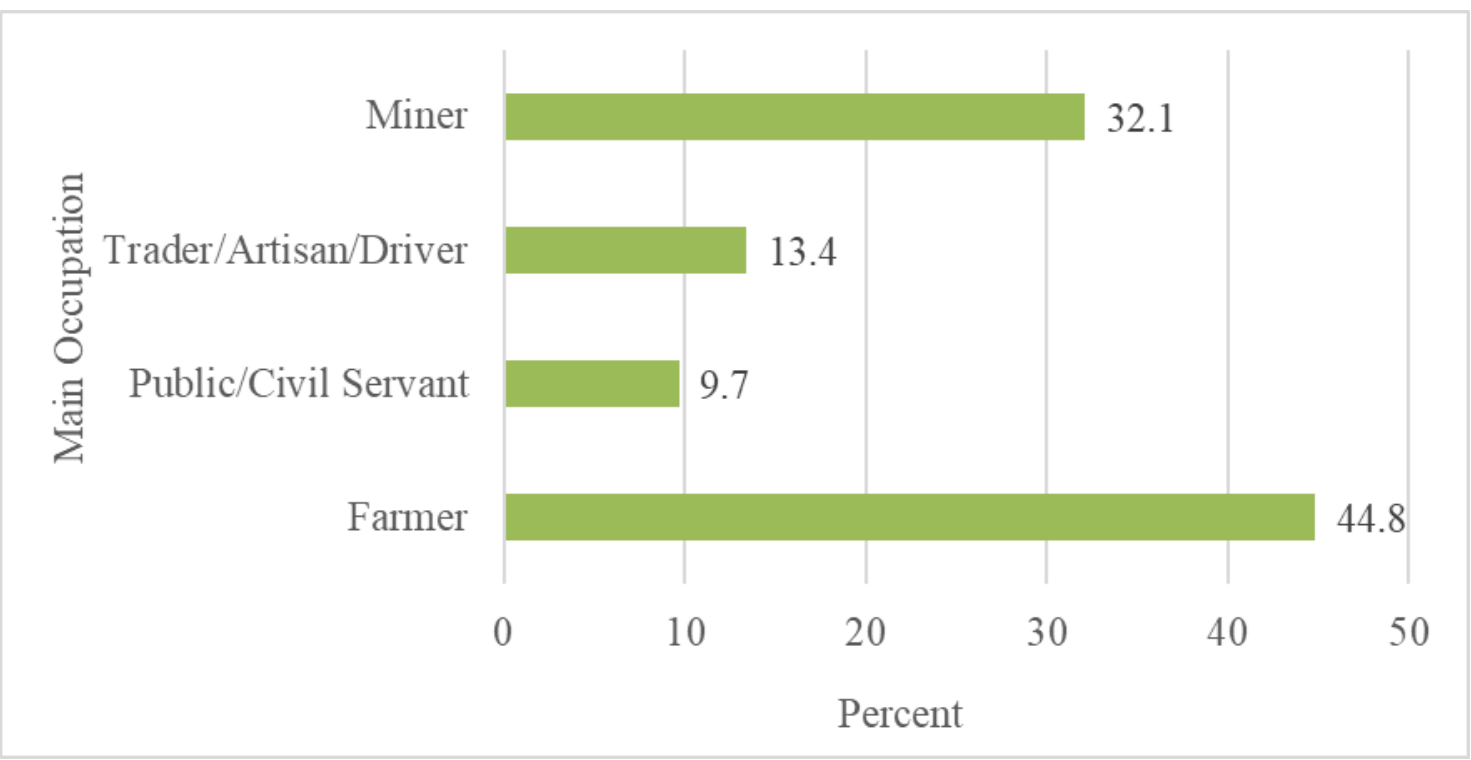

Figure 1: Main occupation of respondents

Source: Field Survey (2017)

\section{Artisanal mining and smallholder agriculture relationship}

The survey results show the majority $(76.2 \%)$ of the respondents participate in ASM at various levels. In addition, an analysis was performed by comparing respondents' age with their level of participation in mining (Table 3). The results revealed that respondents who sponsor miners had the highest mean age of 43 , while those who work temporarily when in financial distress had a mean age of 37.6. The maximum age was 71 and represented respondents who do not participate in mining. Furthermore, the average age of respondents who engaged in mining during the offfarm season was 39.2. The majority $(76.2 \%)$ of the study respondents engaged in mining activities. Respondents' level of participation in mining activities showed $37.6 \%$ of them worked permanently as miners while least $(2.8 \%)$ represents respondents who sponsor miners. 
Table 3: Level of participation in mining

\begin{tabular}{|c|c|c|c|c|c|c|}
\hline Respondent participates in ASM & \multicolumn{2}{|c|}{ Frequency } & \multicolumn{3}{|c|}{ Percent } & \\
\hline Yes & \multirow{2}{*}{\multicolumn{2}{|c|}{221}} & & \multicolumn{2}{|c|}{76.2} & \\
\hline No & & & & & & \\
\hline \multicolumn{7}{|l|}{ Descriptive statistics of age of respondents } \\
\hline $\begin{array}{l}\text { Respondent Level of Participation in } \\
\text { Mining }\end{array}$ & $\mathrm{N}$ & Min. & Max. & Mean & $\begin{array}{l}\text { Std. } \\
\text { Dev. }\end{array}$ & Percent \\
\hline No participation & 69 & 27 & 71 & 41 & 11.92 & 23.8 \\
\hline I work permanently as a miner & 109 & 28 & 65 & 40 & 8.44 & 37.6 \\
\hline I engage in mining occasionally & 61 & 28 & 62 & 41 & 8.34 & 21.0 \\
\hline I only sponsor miners to mine & 8 & 35 & 55 & 43 & 5.95 & 2.8 \\
\hline $\begin{array}{l}\text { I sometimes work temporarily when } \\
\text { in need }\end{array}$ & 21 & 30 & 51 & 38 & 6.82 & 7.2 \\
\hline $\begin{array}{l}\text { I engage in mining during the off- } \\
\text { farm season }\end{array}$ & 22 & 23 & 70 & 39 & 10.79 & 7.6 \\
\hline Total & 290 & 23 & 71 & 41 & 9.41 & 100.0 \\
\hline
\end{tabular}

Source: Field Survey (2017)

The results suggest that artisanal mining is done by the economically active population in the Wa East District. The results further indicate that mining attracts people from all walks of life except those that are very old, incapacitated or minors. This revealation buttresses the findings of Andrews (2015) who reported that, despite the risky nature of the small-scale mining enterprise, it continues to attract people from different socio-economic groups including women and children. Artisanal and small-scale mining is seen as a promising enterprise in most rural communities. Funoh (2014) evaluated and concluded that artisanal mining is more profitable than food crop farming. Considering the seasonal nature of farming in Northern Ghana, most rural farmers become redundant during the dry season (Mumin, 2017). These people, therefore, use mining as a means of engaging themselves during the off-farm season. Besides, some people are attracted to mining because it is a means of getting quick money (Hilson et al., 2014; Andrews, 2015). The results further suggest that some people have taken artisanal mining as a 
Livelihood implications of artisanal gold mining in farming communities: insight from the Wa East District, Ghana

dependable job, thus any attempt to halt the operations of artisanal miners in these communities will have a dire effect on their livelihood.

The results further show that $85.2 \%$ of miners were engaged in farming; $80.7 \%$ were subsistence farmers while $4.5 \%$ were commercial farmers (Table 4). Farming is considered the main occupation of rural dwellers particularly in Sub-Sharan Africa (Funoh, 2014). The situation is not different in the Wa East District; however, agriculture in recent times is faced with several challenges making profit margins to be very low (Hilson, 2016). According to Fearon et al. (2015), it is as a result of the imperfections in the agricultural sector that compels rural dwellers to search for alternative sources of livelihoods, hence, their engagement in mining and other primary activities. Mining has now become the most sought-after job in local communities (Mapuva \& Dube, 2016; Baddianaah et al., 2021). As a result, discussions on streamlining artisanal and small-scale mining must take into account the views of local miners and traditional rulers (Osei-Kojo \& Andrews, 2016). The livelihood trajectory of artisanal mining must first be assessed towards developing and implementing programmes that would not alienate local communities of their livelihood in mining. The results further suggest that the majority of the study respondents are subsistence farmers who may consider ASM as a supplementary income source. This finding corroborates that of Mapuva \& Dube (2016) who maintained that income accrued from artisanal and small-scale mining play an instrumental role in reducing poverty in rural areas. 
Table 4: Participate in farming

\begin{tabular}{lll}
\hline Respondent takes part in farming & Frequency & Percent \\
\hline Yes & 247 & 85.2 \\
No & 43 & 14.8 \\
\hline Type of Farming & Frequency & Percent \\
\hline Subsistence farming & 234 & 80.7 \\
Commercial farming & 13 & 4.5 \\
No participation & 43 & 14.8 \\
\hline Total & 290 & 100 \\
\hline
\end{tabular}

Source: Field Survey (2017)

The mean monthly income of respondents from mining stood at $\mathrm{GH} \not 1,217.43$, approximately US\$ 201.2 while that of other economic activities was GHф524.28, approximately US\$ 86.7 (US\$1= GH $\varnothing 6.05$ as of September 1, 2021). Furthermore, a correlation analysis was performed on the associations between household total income, mining income, farming income and income from other economic activities (Table 5). The results showed that income from mining has a significant positive correlation with the entire household's monthly income. The correlation coefficient of 0.901 was significant at $1 \%$ and this suggests that income from mining has a direct relationship with the entire household income. Besides, income from other economic activities other than mining also increases with an increase in the entire household income as well as income from farming. The correlation coefficients of 0.43 and 0.17 respectively, however, do not indicate a strong association (Table 5). 
Livelihood implications of artisanal gold mining in farming communities: insight from the Wa East District, Ghana

Table 5: Further analysis of respondents' income

\begin{tabular}{|c|c|c|c|c|c|}
\hline Variable & $\mathrm{N}$ & Minimum & Maximum & Mean & $\begin{array}{l}\text { Std. } \\
\text { Deviation }\end{array}$ \\
\hline $\begin{array}{l}\text { Monthly income } \\
\text { from mining }\end{array}$ & $\begin{array}{ll}(\mathrm{GH} \phi) & 218\end{array}$ & 200 & 5000 & 1217.43 & 773.760 \\
\hline $\begin{array}{l}\text { Monthly income } \\
\text { from other activities }\end{array}$ & $(\mathrm{GH} \phi) \quad 116$ & 30 & 2000 & 524.28 & 478.608 \\
\hline \multicolumn{6}{|l|}{ Correlations } \\
\hline Income Sources: & Mining income & $\begin{array}{l}\text { Other } \\
\text { Activitie }\end{array}$ & Economic & $\begin{array}{l}\text { Farming } \\
\text { Income }\end{array}$ & $\begin{array}{l}\text { Household } \\
\text { income }\end{array}$ \\
\hline $\begin{array}{ll}\text { Monthly } & \text { income } \\
\text { (mining) }\end{array}$ & 1 & & & & \\
\hline $\begin{array}{l}\text { Monthly income } \\
\text { (other activities) }\end{array}$ & $\begin{array}{l}0.005 \\
(0.937)\end{array}$ & 1 & & & \\
\hline $\begin{array}{l}\text { Monthly income } \\
\text { (farming) }\end{array}$ & $\begin{array}{l}-0.011 \\
(0.858)\end{array}$ & $\begin{array}{l}0.171^{* *} \\
(0.003)\end{array}$ & & 1 & \\
\hline Household Income & $\begin{array}{l}0.901^{* *} \\
(0.000)\end{array}$ & $\begin{array}{l}0.433^{* *} \\
(0.000)\end{array}$ & & $0.123^{*}(0.037)$ & 1 \\
\hline
\end{tabular}

Source: Field Survey (2017)

However, the relationship between income from mining and income from farming is negative.

Even though the evidence is not significant, it still suggests that artisanal mining and farming are competitive economic activities in the Wa East District. This means that respondents that are into mining showed little attention to farming. The results also show a positive relationship between income from farming and that of the entire household income. It can, therefore, be argued that higher earnings from mining activities have been the force behind most rural farmers shifting to artisanal mining in local communities (Fearon et al., 2015; Osumanu, 2020). Although mining has both positive and negative contributions across local communities, emphasis should be on exploring the positive aspects of artisanal mining by subscribing to sustainable mining strategies. Alternatively, farming should be enhanced to make it dependable and lucrative to sustain and divert the attention of the rural dwellers to it. This would consequently reduce the environmental stress from mining. 


\section{Contribution of artisanal mining to local community development}

Of the benefits derived from artisanal mining, the majority of the respondents $(98.3 \%)$ indicated miners could purchase vehicles such as tractors, cars, and motorbikes through artisanal mining. Artisanal mining adds value to the local economy (95.2\%) and also creates employment opportunities (94.5\%) in local communities, among a host of benefits (Table 6). Most people in mining communities are often divided when discussing its benefits. Thus, while some people may be interested in pointing out its environmental and socio-economic negative effects, others see it as a tool for socio-economic development and empowerment. This buttresses the argument put forward by Crawford \& Botchwey (2016) that artisanal mining in Ghana is a controversial livelihood enterprise.

Table 6: Benefits derived from artisanal mining

\begin{tabular}{lll}
\hline Community benefits & Frequency & Percent \\
\hline Yes & 217 & 74.8 \\
No & 73 & 25.2 \\
List of benefits derived from artisanal mining & \\
Purchase of vehicles (tractors, lorries, cars, motorbikes, etc.) & 285 & 98.3 \\
Block buildings & 277 & 95.2 \\
Employment & 274 & 94.5 \\
Boost the local economy & 201 & 69.3 \\
Support building of community projects & 199 & 68.3 \\
\hline
\end{tabular}

Source: Field Survey (2017)

(Multiple responses were considered)

The results suggest that artisanal mining has impacted positively on the study area. The results further indicate that rural communities are benefiting from artisanal mining in diverse ways. They consider artisanal mining as the main driver of the local economy and a tool for community development. These findings are in tandem with those of (Mapuva \& Dube, 2016; Hilson, 2016). 
Livelihood implications of artisanal gold mining in farming communities: insight from the Wa East District, Ghana

Additionally, another lead miner in response to a question posed on the benefits of artisanal mining had this to say:

What is sustainable livelihood when I am living in a mud and thatch house? You see, my brother let us be frank with the issue here. Most of the youth in this community who can boast of a decent accommodation got it from artisanal mining. As you can see around you, all these blockhouses are from the proceeds of artisanal mining, so is this different from development? Our grandparents were great farmers but we cannot pinpoint any tangible asset bequeathed us, they can only boast of feeding us. (Source: key informant interview at Manwe, 2017).

The account above is suggestive that mining is more rewarding than food crop farming and that rural dwellers in local mining communities prefer artisanal mining to food crop farming. This is because artisanal mining yields more financial relief and a source of quick money compared to food crop farming (Funoh, 2014; Fearon et al., 2015). Linking up to this submission, an Assemblymember in one of the communities in the study area buttressed the argument by stating that:

Frankly speaking, mining in this community has some negative effects, but I will say it has helped our community a lot. I am a teacher and I can tell you that I am the only young man in this community that can boast of putting up a blockhouse without engaging in mining. All these blockhouses you can see around are the product of the galamsey activity. So I will suggest that the government streamlines their operations rather than terminating them completely. (Source: Key informant Interview at Manwe, 2017)

Another miner who was emphatic on the benefits of artisanal mining in the community compared his present accommodation (block painted house) with his previous place of abode (mud/thatched house) when he was a farmer. According to this miner: "Mining has greatly transformed my life. I never thought I could build my blockhouse, but through this mining activity and the grace of God, it has happened." This revelation suggests that artisanal mining in the Wa East District has played a significant role as a livelihood enterprise. It has become a 
reliable source for rural dwellers to obtain funds to provide for themselves shelter and other physical assets like cars, motorbikes, and settling other financial commitments. This, therefore, suggests that any attempt to take local miners out of mining must come with corresponding alternative livelihood strategies that are capable of guaranteeing them similar returns they gain from artisanal mining. Thus, the measures employed by the government of Ghana to end artisanal mining must define and align their operations to sustainable alternative livelihood strategies (Adonteng-Kissi, 2017; Adonteng-Kissi \& Adonteng-Kissi, 2018). One significant way to address the artisanal mining challenges in Ghana is to integrate local miners into the small-scale mining framework.

Furthermore, empirical studies on the relationship between agriculture and artisanal mining shared divergent views on the influence of artisanal mining on agriculture. Boadi et al. (2016) submit that artisanal mining degrades agricultural lands and renders the livelihoods of rural dwellers in mining areas miserable. However, Mapuva \& Dube (2016) believe that rural agriculture depends on artisanal mining because the miners use the proceeds from mining to support agriculture. This stands to explain that dwellers of artisanal mining communities are reaping the benefits of mining. They consider mining to be more rewarding than smallholder agriculture. A miner at Buna had this to say:

As for me mining is not my main job, I am a farmer. But you know in this part of our country, farming has become expensive due to climate variability. If you don't apply fertilizer and chemicals you will not get anything. Because of this, I always engage in mining during the off-farm season so that I can earn something to buy farm inputs for the coming farming season. Is this not better than not doing anything at all? We only need guidance from the experts but not the way they go about criminalizing the business. (Source: Key informant interview at Buna, 2017) 
A lead miner also interviewed in connection with how artisanal mining aids them in farming presented a chain of positive linkages between farming and mining. He explained that:

There is an inseparable nexus between mining and farming in this village. Gone are the days when we had to gather all our money together, ggave it to a tractor operator before he will then come and plough for us. It was not easy getting a tractor; they sometimes took our money and failed to come. But as I am speaking now, two people from this our village bought tractors last year through mining and it makes access to tractor services easier. (Source: Field survey at Baayiri, 2017).

These expressions explain that if rural farmers are supported with farm inputs, the agricultural sector may command equal attention like artisanal mining from rural dwellers. These findings provide ample evidence that artisanal mining has positive effects on agricultural output in the Wa East District although it deprives some people of their farmlands (Bagah et al., 2016).

\section{Local communities' perspectives on the adverse effects of artisanal mining}

From Table 7, about $45.5 \%$ of the study respondents indicated that mining has negative effects on their communities while $54.5 \%$ could not see anything bad with the operations of artisanal miners in their communities. Also, about $75.5 \%$ of the sample indicated that artisanal mining has destroyed their farmlands while $94.5 \%$ of the respondents think it leads to a high incidence of school dropouts. Also, $67.9 \%$ stated that it leads to a shortage of labour at farms for agricultural production. Other negative effects listed included an increase in teenage pregnancy and a high cost of living in the area. The results indicated that artisanal mining has negative effects in the Wa East District. But those who are directly involved in it have failed to truly point out some of these adverse effects. These adverse effects have been reported by several studies (e.g. 
Agyemang \& Okoto, 2014; Bagah et al., 2016; Boadi et al., 2016; Owusu et al., 2019;

Baddianaah et al., 2021).

Table 7: Negative effects of artisanal mining

\begin{tabular}{llc}
\hline SSM has negatively affected the community & Frequency & Percent \\
\hline Yes & 132 & 45.5 \\
No & 158 & 54.5 \\
Negative effects of small-scale mining & & \\
High incidence of school dropout & 274 & 94.5 \\
Destruction of farmlands & 219 & 75.5 \\
Shortage of farm labour & 197 & 67.9 \\
Increase in teenage pregnancy & 196 & 67.6 \\
High incidence of accidents/injuries & 165 & 56.9 \\
Increase in cost of living & 149 & 51.3 \\
\hline Pollution of drinking water sources & 117 & 40.5 \\
\hline \multirow{2}{*}{ Source: Field Survey (2017) } & \multirow{2}{*}{ (Multiple responses were considered) }
\end{tabular}

Furthermore, from closed observation, it was realized that the greatest visible negative environmental effect of mining across the study communities was the destruction of farmlands. Most mining sites visited revealed various levels of degradation including the destruction of plant and animal habitats (Figure 4). It was observed that any woody piece of land that is subjected to mining-related activities was turned into complete bare land. This confirms the degree of land degradation attributed to mining activities in the Wa East District reported by Bagah et al. (2016). 


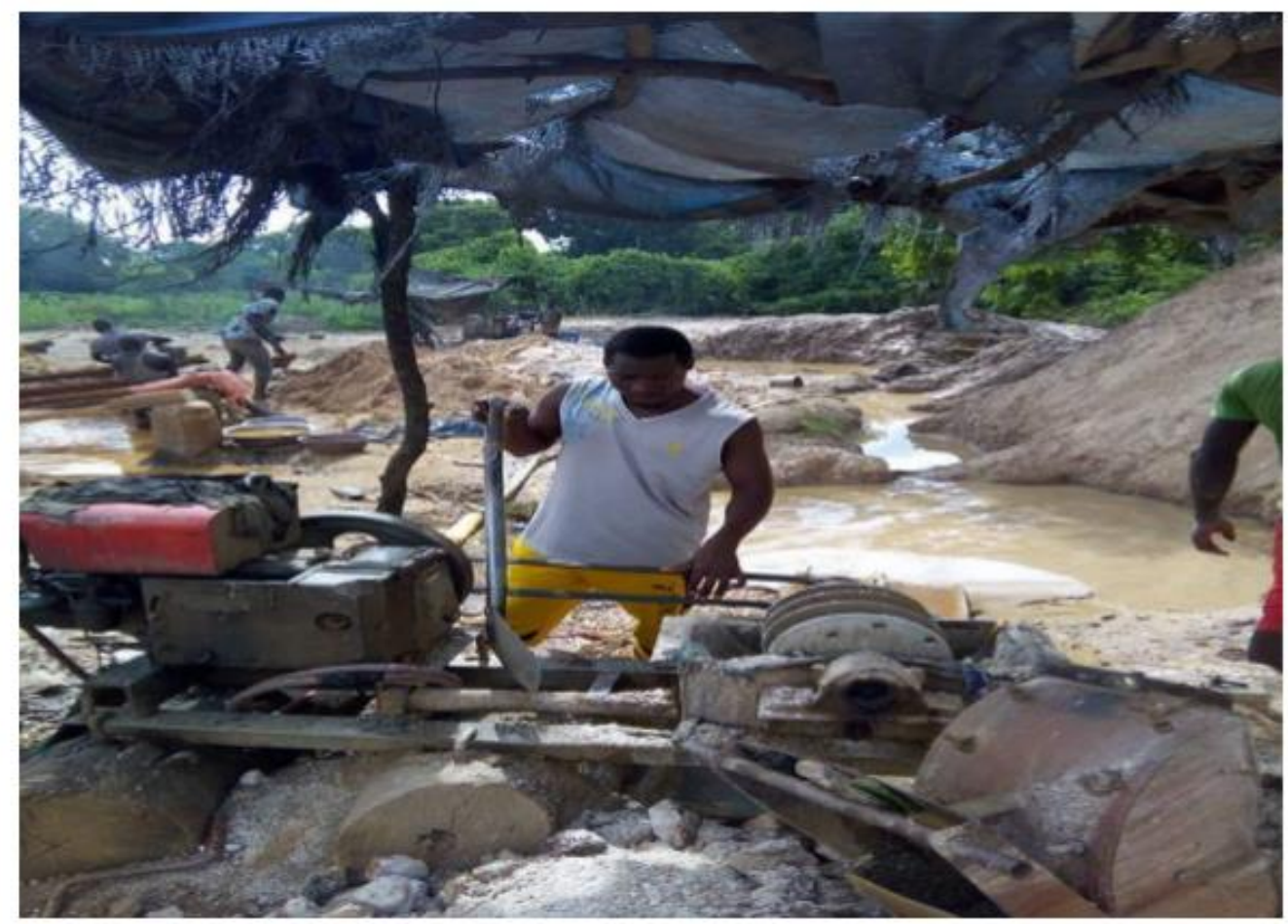

Figure 4: A picture depicting the adverse effects of ASM on Farmlands Source Field Survey (2017)

Considering the adverse effects of artisanal mining operations in the study area, the study sought to find out respondents' views as to whether artisanal mining operations should be permitted to continue or be abolished in their communities. From the results, the majority of the respondents (94.1\%) supported the notion that artisanal mining should be allowed to continue in their communities. Besides, respondents share varied opinions on the challenges their communities are likely to face should mining be abolished (Table 8 ). From the results, $81.1 \%$ of the respondents are of the view that the youth would out-migrate to other places where better opportunities exist, $77.6 \%$ of respondents think it would lead to the prevalence of armed robbery in the area and other social vices. About $96.3 \%$ of respondents think it would collapse the local market and increase poverty and unemployment in the area. This overwhelming support given to the artisanal mining business stands to explain that, although mining communities are faced with 
some negative environmental and social consequences, (Fearon et al., 2016; McQuilken \& Hilson, 2016; UNDP Ghana, 2016), the dwellers benefiting from it will, therefore, want artisanal mining to continue. Thus, most artisanal mining communities see the benefits of the enterprise to be encouraging and would want to continue mining despite the negative effects of the operations as earlier on revealed by Agyemang \& Okoto (2014). As such, national policies that seek to end artisanal mining operations must outline specific policy options for integrating local miners into the mainstream small-scale mining framework. The new small-scale mining policy framework (Owusu et al., 2019) needs to address the fundamental challenges of rural livelihood diversification in order not to dispossess local miners of their livelihood in mining.

Table 8: Small-scale mining to continue in the community

\begin{tabular}{lcc}
\hline Small-scale mining to continue & Frequency & Percent \\
\hline Yes & 273 & 94.1 \\
No & 17 & 5.9 \\
\hline Effects if mining is abolished & 279 & 96.3 \\
Collapse of the local market & 255 & 87.8 \\
Poverty & 248 & 85.4 \\
Unemployment & 235 & 81.1 \\
Youth out-migration & 225 & 77.6 \\
Increased in armed robbery and other social vices & \multicolumn{2}{c}{ (Multiple responses were used) }
\end{tabular}

\section{Conclusion}

The study assessed the contribution of artisanal gold mining activities to smallholder agriculture in the Wa East District. The theory of accumulation by dispossession and the sustainable livelihood approach was employed in outlining both the positive and negative effects and approaches to engaging in sustainable ASM. The findings revealed that rural dwellers express greater interest in artisanal mining compared to farming. The results indicated a strong linkage between artisanal mining activities and smallholder agriculture. Proceeds from artisanal mining 
Livelihood implications of artisanal gold mining in farming communities: insight from the Wa East District, Ghana

are invested in agriculture such as purchasing of farm inputs. The study brings to the fore that artisanal mining could impact positively on local community development and poverty eradication if the bottlenecks in the sector are adequately addressed. However, mining activities affect agriculture through shortage of labour and degradation of farmland. Engaging local miners in minerals decision-making, provision of technical support to local miners will add immensely to promoting sustainable livelihood in rural communities. Also, the plethora of problems associated with artisanal mining across rural communities in Ghana including the Wa East District go beyond arresting and prosecuting miners. The Ghana Education system should take up the task of introducing courses on participatory resource governance and sustainable mining across all levels of the educational curriculum. Finally, the study calls on the Government of Ghana to expedite action on the implementation of the Community Mining Cooperative projects to enable rural communities to mine legally.

\section{Acknowledgments}

We would like to extend our appreciation to Mr. Motin Bashiru, Mr. Inusah Adama Abu, Mr. Abudi Iddrisu, and Mr. Ismail Yorgah Kangbuarah for the diverse support you offered during the field data collection.

\section{Funding}

This research did not receive any specific grant from funding agencies in the public, commercial, or not-for-profit sectors. 


\section{References}

Abdulai, A. G. (2017). Competitive clientelism and the political economy of mining in Ghana. ESID Working Paper No. 78. Manchester, UK: The University of Manchester. http://www.effective-states.org/wp-content/uploads/working_papers/finalpdfs/esid_wp_78_abdulai.pdf

Adonteng-Kissi, O. (2017). Poverty and mine's compensation package: Experiences of local farmers in Prestea mining community. Resources Policy, 5: 226-234. DOI: 10.1016/j.resourpol.2017.03.007

Adonteng-Kissi, O., \& Adonteng-Kissi, B. (2018). Precarious work or sustainable livelihoods? Aligning Prestea's Programme with the development dialogue on artisanal and smallscale mining. Natural Resource Forum, 42: 123-137. https://doi.org/10.1111/14778947.12147

Aggarwal, Y. P. (2008). Science of Educational Research, Nirmal Book Agency.

Agyemang, I., \& Okoto, H. (2014). Small-scale mining activity in Mengwe Community, Northern Ghana: Advantages amidst the disadvantaged socio-economic effects. International Journal of Educational Research and Development, 3(2): 23-29. http://www.academeresearchjournals.org/journal/ijerd

Akabzaa, T. M., \& Darimani, A. (2001). Impacts of mining sector investment in Ghana: a study of the Tarkwa Mining Region. Accra: SAPRI Ghana. http://www.saprin.org/ghana/research/gha_mining.pdf

Andrews, N. (2015). 'Digging for survival and/or justice?: the drivers of illegal mining activities in Western Ghana, in Africa Today, 62 (2): 1-24. https://www.researchgate.net/deref/http\%3A\%2F\%2Fdx.doi.org\%2F10.2979\%2Fafricato day.62.2.3

Apuri, I., Peprah, K., \& Achana, G. T. W. (2018). 'Climate change adaptation through agroforestry: the case of Kassena Nankana West District, Ghana'. Environmental Development, 28: 32-41. DOI: 10.1016/j.envdev.2018.09.002

Awumbila, M., \& Tsikata, D. (2004). Migration dynamics and small scale gold mining in northeastern Ghana: implications for sustainable rural livelihoods. Legon: University of Ghana. https://uaps2007.princeton.edu/papers/70506

Ayee, J., Søreide, T., Shukla, G. P., \& Minh Le, T. (2011). Political economy of the mining sector in Ghana. Policy Research Working Paper 5730. The World Bank Africa Region, Public Sector Reform and Capacity Building Unit. https://www.cmi.no/publications/file/4091-political-economy-of-the-mining-sector-inghana.pdf

Baddianaah, I., Peprah, K., \& Adams, A. (2021). Exploring spirituality, successes, and land degradation nexus in small-scale gold mining (galamsey) in Ghana: Evidence from the Wa East District. Journal of Environmental \& Agricultural Sciences. 23(1\&2): 19-29.

Baddianaah, I., Peprah, K., \& Yembilah, N. N. (2020). Nexus between smallholder irrigation farming and farmers' livelihood outcomes in Ghana's Guinea Savannah. International Journal of Irrigation and Agricultural Development (IJIRAD), 4(1), 221-233. https://doi.org/10.47762/2020.964x.81 
Bagah, D. A., Angko, W., \& Tanyeh, J. P. (2016). Environmental degradation and small-scale mining nexus: emerging trends and challenges in Northern Ghana. Developing Country Studies, 6 (2): 38-45. https://iiste.org/Journals/index.php/DCS/article/view/28617/29379

Bhattacherjee, A. (2012). "Social science research: principles, methods, and practices".Textbooks.Collection.Book3.http://scholarcommons.usf.edu/oa_textbooks/3

Boadi, S., Nsor, C. A. Antobre, O. O., \& Acquah, F. (2016). An analysis of illegal mining on the Offin Shelterbelt Forest Reserve, Ghana: implications on community livelihood. Journal of Sustainable Mining, 15: 115-119. http://dx.doi.org/10.1016/j.jsm.2016.12.001

Boateng, D. O., Codjoe F. N. Y., \& Ofori, J. (2014). Impact of illegal small-scale mining (Galamsey) on cocoa production in Atiwa District of Ghana. International Journal of Advance Agricultural Research, 89-99. http://www.bluepenjournals.org/ijaar/pdf/2014/July/Boateng_et_al.pdf

Cáceres, D. M. (2015). Accumulation by dispossession and socio-environmental conflicts caused by the expansion of agribusiness in Argentina. Journal of Agrarian Change, 15 (1): 116147. https://doi.org/10.1111/joac.12057

Chambers, R., \& Conway, G. (1992). Sustainable Rural Livelihoods: Practical Concepts for the 21st Century. IDS Discussion Paper 296, IDS, Brighton.

Crawford, G., \& G. Botchwey. (2016). Conflict, collusion and corruption in small-scale gold mining in Ghana: Chinese miners and the state. Global governance/politics, climate justice and agrarian/social justice:

linkages and challenges.An international colloquium.International Institute of Social Stud ies (IS). $\quad$ Paper $\quad$ No. $48 . \quad$ https://www.iss.nl/sites/corporate/files/48ICAS_CP_Crawford_and_Botchwey.pdf

Creswell, J. W. (2014). Research design: qualitative, quantitative, and mixed methods approach $\left(4^{\text {th }}\right.$ ed). $\quad$ Thousand $\quad$ Oaks, $\quad$ CA: https://www.researchgate.net/deref/http\%3A\%2F\%2Fdx.doi.org\%2F10.5539\%2Felt.v12 $\mathrm{n} 5 \mathrm{p} 40$

DFID. (2000). Framework introduction. Sustainable livelihoods guidance sheets. (available at: http://www.eldis.org/go/topics/dossiers/livelihoods-connect/what-arelivelihoodsapproaches/training-and-learning-materials).

Fearon, J., Agbah, N., \& Dawutey, E. (2015). Perspectives on small-scale mining in the Birim North District of Ghana. Journal of Environment and Earth Science, 5(16): 86-94. https://www.iiste.org/Journals/index.php/JEES/article/viewFile/25205/25809

Funoh, K. N. (2014). The impacts of artisanal gold mining on local livelihoods and the environment in the forested areas of Cameroon. Working Paper 150. Bogor, Indonesia: CIFOR. http://www.cifor.org/publications/pdf_files/WPapers/WP150CIFOR.pdf

Ghana Statistical Service [GSS]. (2014). 2010 Population and housing census. District Analytical Report, Wa East District. https://www2.statsghana.gov.gh/docfiles/2010_District_Report/Upper\%20West/Wa\%20 West.pdf

Harvey, D. (2003). The new imperialism. Oxford and New York: Oxford University Press. http://eatonak.org/IPE501/downloads/files/New\%20Imperialism.pdf

Hilson, G. (2016). Artisanal and small-scale mining and agriculture: exploring their links in rural sub-Saharan Africa. IIED, London. https://pubs.iied.org/pdfs/16617IIED.pdf 
Hilson, G., \& Garforth, C. (2012). 'Everyone now is concentrating on the mining': drivers and implications of rural economic transition in the eastern region of Ghana. The Journal of Development Studies, 49(3): 348-364. https://doi.org/10.1080/00220388.2012.713469

Hilson, G., Hilson, A., \& Adu-Darko, E. (2014). Chinese participation in Ghana's informal gold mining economy: Drivers, implications and clarifications. Journal of Rural Studies, 34(1): 292-303. https://doi.org/10.1016/j.jrurstud.2014.03.001

Kidido, J. K., Ayitey, J. Z., Kuusaana. E. D., \& Gavu. E. K (2015). Who is the rightful recipient of mining compensation for land use deprivation in Ghana? Resources Policy, 43: 19-27. 10.1016/j.resourpol.2014.10.004

Krantz, L. (2001). The Sustainable livelihood approach to poverty reduction. Swedish International Development Cooperation Agency (SIDA), Stockholm, Sweden. https://www.sida.se/contentassets/bd474c210163447c9a7963d77c64148a/thesustainable-livelihood-approach-to-poverty-reduction_2656.pdf

Mapuva, J., \& Dube, M. (2016). Small-scale gold mining and rural livelihoods: Case of Wozoli Silobela Ward 22, Kwekwe District (Zimbabwe). Journal of Progressive Research in $\begin{array}{lllll}\text { Social } & \text { Sciences } & \text { (JPRSS), } & 3 & \text { (2): }\end{array}$ http://scitecresearch.com/journals/index.php/jprss/article/view/574

Marx, $\quad$ K.(1976).Capital, $\quad 1 . \quad$ London: https://www.surplusvalue.org.au/Marxism/Capital\%20-\%20Vol.\%201\%20Penguin.pdf

McQuilken, J., \& Hilson, G. (2016). Artisanal and small-scale gold mining in Ghana. Evidence to inform an 'action dialogue'. IIED, London. https://pubs.iied.org/16618IIED/

Mihaye, J. (2013). Small-scale mining operations and their effects in the East Akim Municipal Assembly. MPhil. Thesis, University of Ghana, Legon. https://citeseerx.ist.psu.edu/viewdoc/download?doi=10.1.1.892.3999\&rep=rep1\&type=pd $\underline{f}$

Ministry of Land and Natural Resources [MLNR]. (2012). Implementation of Ghana shared growth and development agenda (GSGDA). Annual progress report, Accra, Ghana.

Morse, S., \& McNamara. N. (2013). Sustainable livelihood approach, Springer Science+Business Media, Dordrecht. http:/doi-org443.webvpn.fjmu.edu.cn/10.1007/978-94-007-6268-8_3

Mumin A. Y. (2017). 'Small-scale irrigation, farm income and access to essential services in the Busa Community of the Upper West Region of Ghana'. Ghana Journal of Development Studies, 14 (10): 99-122. http://dx.doi.org/10.4314/gjds.v14i1.6

Neuman, W. L. (2014). Social research methods: qualitative and quantitative approaches $\left(7^{\text {th }}\right.$ ed.). Pearson New International. http://letrunghieutvu.yolasite.com/resources/wlawrence-neuman-social-research-methods_-qualitative-and-quantitative-approachespearson-education-limited-2013.pdf

Ofosu-Mensah, A. E. (2011). Traditional gold mining in Adanse. Nordic Journal of African Studies 19(2): 124-147. http://www.njas.helsinki.fi/pdffiles/vol19num2/ofosu_mensah.pdf

Osei-Kojo, A., \& Andrews, N. (2016). Questioning the status quo: can stakeholder participation improve implementation of small-scale mining laws in Ghana? Resources, 5(33): 1-16. $\underline{10.3390 / \text { resources } 5040033}$ 
Osumanu, I. K. (2020). Small-scale mining and livelihood dynamics in North-Eastern Ghana: Sustaining rural livelihoods in a changing environment. Progress in Development Studies, 1-15. https://doi.org/10.1177/1464993420934223

Owusu, O., Bansah, K. J., \& Mensah, A. K (2019). "Small in size, but big in impact": socioenvironmental reforms for sustainable artisanal and small-scale mining. Journal of Sustainable Mining, 18: 38-44. https://doi.org/10.1016/j.jsm.2019.02.001

Panneerselvam, R. (2011). Research methodology. PHI Learning Private Limited, New Delhi110001.

Panneerselvam/dp/8120349466 https://www.amazon.com/Research-Methodology-R-

Redehey, B. G. (2017). Youth in artisanal gold mining: risks and opportunities; the case of Asgede Tsimbla Woredai, Northwestern Tigray National Regional State, Ethiopia. International NGO Journal, 12(3): 22-28. https://doi.org/10.5897/INGOJ2016.0320

Republic of Ghana. (2006). The Minerals and Mining Act, 2006, Act 703, Accra. Republic of Ghana (1992) 'The constitution of the Republic of Ghana 1992', http://www.judicial.gov.gh/constitution/chapter/chap_1. htm

Scoones, I. (2009). Livelihoods perspectives and rural development. Journal of Peasant Studies, 36(1): 171-196. https://doi.org/10.1080/03066150902820503

UNDP Ghana. (2016). Social analysis of Ghana's artisanal and small-scale mining sector. Final Report.

Accra, Ghana. file:///C:/Users/Fear\%20everywhere/Downloads/UNDP_GH_INCGRO_ASM-SocialAnalysis-Final3modified.pdf

Yamane, T. (1967). Statistics: an introductory analysis ( $2^{\text {nd }}$ ed.). Harper and Row, New York. https://www.worldcat.org/title/statistics-an-introductory-analysis-2nd-ed/oclc/299725866 